\title{
Cytotoxicity in MCF-7 and MDA-MB-231 Breast Cancer Cells, without Harming MCF-10A Healthy Cells
}

\section{Moses SL ${ }^{1 *}$, Edwards VM' and Brantley $\mathrm{E}^{2}$}

${ }^{1}$ Department of Physics, Alabama Agricultural \& Mechanical University, 4900 Meridian Street North, USA ${ }^{2}$ School of Medicine, Loma Linda University, 11175 Campus St, Loma Linda, CA 92350, USA

\begin{abstract}
Globally, breast cancer in women has become a major issue of concern, especially with treatment methods that are harmful to the patients. This research involved the trisodium citrate dihydrate (TSCD) reduction and capping of gold nanoparticles (AuNPs) to be used as a drug delivery system for Boswellia sacra (BS) and Commiphora myrrha (CM) to induce cytotoxicity in breast cancer cell lines MCF-7 and MDA-MB-231 without harming MCF-10A healthy cells. Characterization and size of nanoparticles were confirmed by UV-Visible Spectroscopy and Transmission Electron Microscopy. A pristine sample of monodispersed gold nanoparticles from $15-20 \mathrm{~nm}$ in size was produced. Pure plant extract was obtained and identification was confirmed using Fourier Transform Infrared Spectrometer and Gas Chromatography Mass Spectrometry. Once synthesized, two concentrations of the compound were sent and tested on breast cancer cell lines MCF-7, MDA-MB-231, and MCF-10A at the Brantley Cancer Research Laboratory at Loma Linda University Health, School of Medicine in Loma Linda, California. Results showed cytotoxicity in both cell lines, more aggressive in triple-negative cells, without harm to healthy MCF-10A cells. Utility Patent has been filed with the USPTO.
\end{abstract}

Keywords: Metal nanoparticles; Nanomedicine; Drug delivery; Breast cancer

\section{Introduction}

Throughout the world, breast cancer in women has become a great concern, especially with treatment methods that cause harmful side effects. Mortality rates have decreased in all ethnic groups with the exception of Native Americans, where the trends remained level [1].

The Director of the IARC, Dr. Christopher Wild, said that "An urgent need in cancer control today is to develop effective and affordable approaches to the early detection, diagnosis, and treatment of breast cancer among women living in less developed countries. It is critical to bring morbidity and mortality in line with progress made in recent years in more developed parts of the world" [2].

Individuals who have been diagnosed with cancer have been treated with surgery, radiation therapy, chemotherapy, hormonal therapy, and targeted therapy (blocking the growth of cancer cells by interfering with specific molecules needed for tumor growth). Current cancer drugs include the following side effects: decreased blood cell counts, mouth ulcers, hair loss, nausea and vomiting, heart damage, allergic reaction, loss of appetite, change in taste, joint pain, numbness or tingling in fingers or toes, diarrhea, photosensitivity, dry skin, labored breathing, kidney damage and more [3]. Chemotherapy kills cancer cells as well as healthy cells, with its host of related side effects.

Advances in our knowledge of the biology of breast cancer have been made over the past several decades, since 1958, using breast cancer cell lines. This study used the MCF-7 and MDA-MB-231 cell lines due to their well-documented studies and different characteristics. The MCF-10A cell line used represented healthy cells to determine the level of safety of the use of this compound in human subjects. This research examined the use of AuNPs with natural healing ingredients that kill cancer cells without harming healthy cells. MCF-7 and MDAMB-231 were analyzed based on their response to citrate reduced gold nanoparticles functionalized with Boswellia sacra and Commiphora myrrha. A compound was created that utilized the combined anticancer effort of AuNPs, Boswellia sacra, and Commiphora myrrha as a natural, triple action effect on breast cancer cell lines MCF-7 and
MDA-MB-231, using AuNPs as a delivery system to cancer sites. This compound can reduce anxiety, inflammation, and relieve pain naturally, as well as cause cytotoxicity of cancerous cells without harming healthy cells.

The purpose of this present study was to discover a natural, safe alternative for the treatment of breast cancer through the use of an emerging field in physics called nanomedicine, the medical application of nanotechnology - the manipulation of matter on an atomic, molecular, and supramolecular scale. Plant extracts were used in conjunction with gold nanoparticles, particles between 15 and 20 nanometers in size to kill cancer cells, and the additional benefits include the alleviation of pain, inflammation and stress in breast cancer patients. There are currently several breast cancer drugs and treatments on the market, however, they cause considerable harm to the healthy cells of the patient. The compound created during this research was proven to cause cytotoxicity in breast cancer cells without causing harm to healthy cells with additional therapeutic advantages due to the synergistic effects of the biological compounds used.

Metal nanoparticles have been increasingly used in nanotechnology and nanomedicine, including clinical diagnostics, therapeutics development, advanced imaging, and drug delivery.

More specifically, gold nanoparticles have been used in the diagnosis and treatment of cancer. Gold nanoparticles, also known as colloidal gold, are a suspension of nanoscale sized particles of gold in

*Corresponding author: Sherita L. Moses, Department of Physics, Alabama Agricultural \& Mechanical University, 4900 Meridian Street North, USA, Tel: 256468-6000; E-mail: smoses2@bulldogs.aamu.edu

Received April 20, 2016; Accepted April 23, 2016; Published April 30, 2016

Citation: Moses SL, Edwards VM, Brantley E (2016) Cytotoxicity in MCF-7 and MDA-MB-231 Breast Cancer Cells, without Harming MCF-10A Healthy Cells. J Nanomed Nanotechnol 7: 369. doi:10.4172/2157-7439.1000369

Copyright: $\odot 2016$ Moses SL, et al. This is an open-access article distributed under the terms of the Creative Commons Attribution License, which permits unrestricted use, distribution, and reproduction in any medium, provided the original author and source are credited. 
a fluid, usually water. Depending on the size of the nanoparticles, the liquid colors range from ruby red $(<100 \mathrm{~nm})$ to blue or purple $(>100$ nm) [4].

According to scientists at Harvard Medical School and Northeastern University, nanomedicine is more advantageous than conventional medicine due to the fact that nanoparticles can be designed to allow specific drug delivery to tumors because of the EPR effect [5].

Theranostics review article, "the positive charges on the nanoparticle surface stimulates cellular uptake due to electrostatic interactions with the cell surface. Positive charges can also improve nanoparticle transport to the nucleus because nuclear localization sequences of many proteins are enriched for basic amino acid residues" [6].

Biologically functionalized AuNPs are safe and have been approved for use by the US Food and Drug Administration which would mean fewer side effects in breast cancer studies [7]. This study functionalized the nanoparticles with Boswellia sacra and Commiphora myrrha.

At the Peninsula Medical School, Universities of Exeter and Plymouth in the United Kingdom, clinical studies were conducted on the use of Boswellia with several illnesses. These data proved that Boswellia extracts are effective in treating a variety of conditions caused or maintained by inflammatory processes [8]. The Boswellia species is reported to contain $60-85 \%$ mixtures of terpenes, $6-30 \%$ polysaccharides, and 5-9\% essential oil. The resin contains pentacyclic triterpenes in which boswellic acid is the active functional group [9]. Boswellic acids are common compounds with differing pharmacological activities to include anti-inflammatory and antitumor activities [10]. According to Dr. Eric L. Zielinski at DrEricZ.com, Dr. Lin, an Associate Professor in the Department of Urology (University of Oklahoma Health Sciences Center), conducted research on frankincense oil that is unparalleled, and he has been able to uncover findings that Boswellia sacra targets breast cancer cells by killing them and leaving the healthy cells unharmed; he determined that frankincense oil derived from Boswellia sacra represses signaling pathways and cell cycle regulators that have been proposed as therapeutic targets for cancer; he suggested that suppression of cellular network formation and disruption of Immunologist Mahmoud Suhail stated that "frankincense exhibits power over our DNA code. Cancer starts when the DNA code within the cell's nucleus becomes corrupted. It seems frankincense has a reset function, as it can tell the cell what the right DNA code should be. Frankincense separates the brain of the cancerous cell (the nucleus), from the body (the cytoplasm), and closes down the nucleus to stop it from reproducing corrupted DA codes" [11,12].

It is believed that increased research materials would provide more opportunities for the discovery of new bioactive principles from the genus Commiphora [13]. Myrrh, a resin obtained from the genera Commiphora, has been used for a long time as a medicine and wound dressing. Myrrh gum is used for indigestion, ulcers, colds, cough, asthma, lung congestion, arthritis pain, and cancer [14]. Pain and inflammation often accompany degenerative diseases including cancers, rheumatoid arthritis and peripheral vascular disease, which cause harm to the patient. The drugs used for these conditions often cause harmful and adverse side effects. Natural substances derived from medicinal plants are more effective and safer than chemically synthesized drugs for the treatment of various diseases including pain and inflammations [15]. In a study done by Gawade it was noted that the mechanism of analgesic activity of Commiphora extract was probably due to its bioactive substances that raised the pain threshold by depressing pain receptors centrally in the brain [16]. In a study conducted in 2013 in Asia, a significant inhibitory effect was noted in the MCF-7 cell lines following treatment with myrrh oil. Their observation indicated that apoptosis may be a major contributor to the biological efficacy of the MCF-7 cells. They also noted that the results indicated that the breast cancer cell line showed increased sensitivity to myrrh [17].

This study reduced gold nanoparticles from Gold Chloride (AuCl3) by using Tri-Sodium Citrate Dihydrate as a capping solution. Once reduced, the AuNPs were synthesized with Commiphora myrrha and Boswellia sacra plant extract, then tested on breast cancer cells as well as healthy cells. This combination of these materials has not been tested on these cell lines, which provided this original opportunity for research. In addition to being toxic to cancer cells, this compound possessed anti-inflammatory and analgesic properties for breast cancer patients, providing a triple threat to this disease, without harming healthy cells.

\section{Methods and Materials}

The Turkevich/Frens method was used, allowing for the production of small spherical nanoparticles, tunable base on the amount of the reducing agent used. These nanoparticles were analyzed and characterized by observance of a ruby red solution during wet chemistry and UV-VIS Spectroscopy and then taken to the High Resolution Shared Imaging Facility at the University of Alabama in Birmingham where Transform Electron Microscopy determined characterization of the nanoparticles.

Circular Whatman filter paper was cut into several pieces in the shape of a wedge similar to cutting a pie. These cut up pieces of filter paper were placed into a petri dish. They were used to dry off liquid on the grids. The sample was then adsorbed onto the grids using fine forceps, picking up the carbon-coated grid face at the edge of the grid. Eight microliters $(\mu \mathrm{l})$ of the sample was placed on the grid and allowed to dry for five minutes. While drying, 0.5 milliliters $(\mathrm{ml})$ of $2 \%$ uranyl acetate was diluted in $0.5 \mathrm{ml}$ of water and spun down at $4^{\circ} \mathrm{C}$ for 5 minutes. The top $0.5 \mathrm{ml}$ was removed for later use. The stock solution of uranyl acetate was weighed and stirred in the fume hood and the solution was heated on a hot plate as it stirred to dissolve the uranyl acetate powder. The solution was cooled before it was removed from the fume hood and the liquid was removed with the cut up wedges of Whatman filter paper and washed twice with PBS by inverting the grid onto two drops of $5 \mu$ l each of PBS applied onto a piece of parafilm.

Finally, $5 \mu \mathrm{l}$ of the $1 \%$ uranyl acetate was applied onto the grid for 10 seconds, removed with Whatman filter paper, and then another 5 ul of the $1 \%$ uranyl acetate was applied for 50 seconds. The grid was then placed onto a grid holder for electron microscopy.

Sodium Chloride Crystal IR cards were obtained from Fisher Scientific. A drop of Boswellia sacra extra was placed on one card, and a drop of Commiphora myrrha was placed on another and allowed to dry in a sealed, plastic container in the Incufridge at $5^{\circ} \mathrm{C}$. The labeled cards were then removed and analyzed on the Fourier Transform Infrared instrument.

Fourier Transform Infrared analysis was completed to observe functional groups present in extracts. The Fourier Transform Infrared (FTIR) used was a Nicolet IS-10 model. 32 scans were completed at a resolution of $8 \mathrm{~cm}^{-1}$ and final format is in absorbance. Air was used as the background in the transmission configuration and data collection was started. Background scans were taken in air before collecting sample spectra. A pipette was used to place a drop or two of the 
solution onto the $\mathrm{NaCl}$ crystal card, sample was loaded and spectrum collected. The OMNIC software was used to convert the spectrum units to absorbance, and the IR Spectral Interpretation

command was used to identify various chemical groups in the sample which was used to compare to materials listed in the library of the system.

Gas Chromatograph Mass Spectrometry was used to identify the components of the Boswellia sacra and Commiphora myrrha extracts. The instrument used was Perkin-Elmer GC-MS Clarus 500. Elite 5 MS Column with a length of $20 \mathrm{~m}$ and internal diameter of $0.18 \mu$ was used. The software used for analysis was Turbo Mass, Wiley Access Mass Spectral Browser 3.2.2 and NIST MS Search 2.0 along with the Wiley Registry of Mass Spectral Data, NIST/EPA/NIN Mass Spectral Library and SDBS Database.

The column oven had an operating temperature of $80^{\circ} \mathrm{C}$ above ambient to $325^{\circ} \mathrm{C}$, with a temperature set point resolution at $1{ }^{\circ} \mathrm{C}$. Petroleum Ether Extract (PELP) and Chloroform Extract (CELP) were subjected to GC-MS studies in Perkin-Elmer GC-MS Clarus 500. Run time was set to $75 \mathrm{~min}$ with a ramp rate of $2^{\circ} \mathrm{C}$ per min up to $190^{\circ} \mathrm{C}$ and with a hold at $50^{\circ} \mathrm{C}$ for $5 \mathrm{~min}$, with an injection volume of $1 \mu \mathrm{l}$. The carrier gas was Helium, $1 \mathrm{ml} / \mathrm{min}$. The mass method used was Electron Ionization (EI+) $70 \mathrm{eV}$ for $\mathrm{m} / \mathrm{z}$ value 50 to 300 with a scan time of $0.3 \mathrm{sec}$ and interscan delay of $0.1 \mathrm{sec}$. Compounds were identified by comparing their mass spectra with those of the National Institute of Standards and Technology (NIST) library. After confirmation of extracts, regular and extra strength amounts were added to different amber bottles of reduced gold nanoparticles, solution magnetically stirred for 30 minutes, then incubated.

The compound was then sent to the Brantley Cancer Cell Biology Lab at Loma Linda University Health, School of Medicine, in Loma Linda, California. Human MDA-MB-231 and MCF-7 breast cancer cell lines as well as human MCF10A breast epithelial cells were obtained from the NCI-Frederick Cancer DCTD tumor/cell line repository. Cells were cultured in RPMI-1640 medium containing 10\% FBS (Hyclone, Logan, UT), $2 \mathrm{mM}$ glutamine and penicillin- streptomycin antibiotic (Mediatech, Herndon, VA). The MCF10A cells were cultured in

Dulbecco's Modified Eagle's Medium/nutrient mixture F-12 (Mediatech, Herndon, VA) supplemented with hydrocortisone (Sigma-Aldrich, St. Louis, MO), human recombinant EGF (SigmaAldrich, St. Louis, MO), 5\% (v/v) horse serum (Invitrogen, Carlsbad, CA), cholera toxin (Calbiochem, BD Biosciences, La Jolla, CA) and penicillin-streptomycin antibiotic (Mediatech). Before use, the compounds were diluted in complete RPMI medium such that the final percentage was no more than $10 \%$, and serial dilutions were made. This low concentration had no appreciable effect on cells. Alamar Blue ${ }^{\mathrm{mt}}$ dye was purchased from BioSource International, (Camarillo, CA).

\section{All other reagents were purchased from Sigma Aldrich.}

The ability of the gold nanoparticle and gold nanoparticle mixtures to impact the viability of MDA-MB-231, MCF-7 and MCF-10A cells was determined using the Alamar Blue ${ }^{\mathrm{mat}}$ assay as previously described. Cells were plated in 96-well plates at their appropriate densities (25,000 cells/well) in a total volume of 100 microliters. After 24-48 hours of incubation, cells were treated with $10 \%$ gold nanoparticle in buffer (control) or gold nanoparticle compound with extracts (regular strength or extra strength) for 72 hours before the addition of 10 microliters of Alamar Blue ${ }^{\mathrm{max}}$ dye. After 4 hours of dye incubation, the plates were read using an FLx800 microplate fluorescence reader (excitation and emission $=530$ and $590 \mathrm{~nm}$ respectively). Following the 72-hour incubation, cells were visualized using relief contrast microscopy.

Apoptotic body formation was observed in cells exposed using an Olympus IX71 inverted microscope with relief contrast imaging. Images were captured using a SPOT digital camera system. MCF10A, MDA-MB-231 and MCF-7 cells were plated in 96 well plates and allowed to attach overnight. The cells were then exposed to gold nanoparticles in buffer (control) or gold nanoparticle compound with extracts at both strengths for 72 hours, and then imaged.

\section{Results}

\section{Gold nanoparticles}

Spherical gold nanoparticles, $15-20 \mathrm{~nm}$ were reduced using the Turkevich/Frens method. The first confirmation of production was a ruby red solution indicating particles $<100 \mathrm{~nm}$. Their identification was confirmed by the analysis of Ultra-Violet Visible Spectrometry shown in Figure 1.

Characterization was determined through the use of Transmission Electron Microscopy evidenced in Figure 2, displaying pristine samples of spherical gold nanoparticles, and $15-20 \mathrm{~nm}$ in size.

\section{Fourier transform analysis of Boswellia sacra and Commiphora myrrha}

The Fourier Transform Infrared (FTIR) used was a Nicolet IS-10 model to identify functional groups in Boswellia sacra and Commiphora myrrha. Thirty-two scans were used and the units are in absorbance. The interpretation of infrared spectra involved the correlation of absorption bands in the spectrum of an unknown compound with the known absorption frequencies for types of bonds. Characteristics for the identification of the source of an absorption band are intensity (weak, medium, or strong), shape (broad or sharp), and position of the spectrum $\left(\mathrm{cm}^{-1}\right)$. The analyses revealed functional groups for Boswellia sacra to include aromatic $\mathrm{CH}$ absorption, $\mathrm{OH}$ acids, and $\mathrm{CH} 3$ groups, and Commiphora myrrha included aromatic $\mathrm{CH}$ absorption, $\mathrm{C}=\mathrm{O}$ absorption, nitro-compounds, amines and $\mathrm{CH} 3$ groups, shown in Figures 3 and 4 .

To help with identification of the peaks, Table 1 was constructed to show the characteristic infrared absorption frequencies.

The positions of atoms in a molecule are not fixed so they are subject to several different vibrations of either stretching or bending. Bending occurs when the angle between two bonds change. Stretching occurs when there is a change in the inter-atomic distance along bond axes (Fourier Transform Infrared Spectroscopy).

\section{GC-Mass spectroscopy analysis of Boswellia sacra and Commiphora myrrha}

These functional groups were further confirmed by Gas Chromatography Mass Spectrometry (GC-MS) identification. This identification shown in Figures 5-8 revealed that the major components of frankincense (BS) were alpha-pinene, limonene, and myrcene, while the major components of myrrh (CM) were nitrofurantoin and diethyl phthalate, as summarized in Table 2.

\section{Breast cancer assays}

Boswellia sacra and Commiphora myrrha coupled with gold nanoparticles diminished the viability of tumorigenic MDA-MB-231 and MCF-7 cells more so than the viability of non-tumorigenic MCF- 


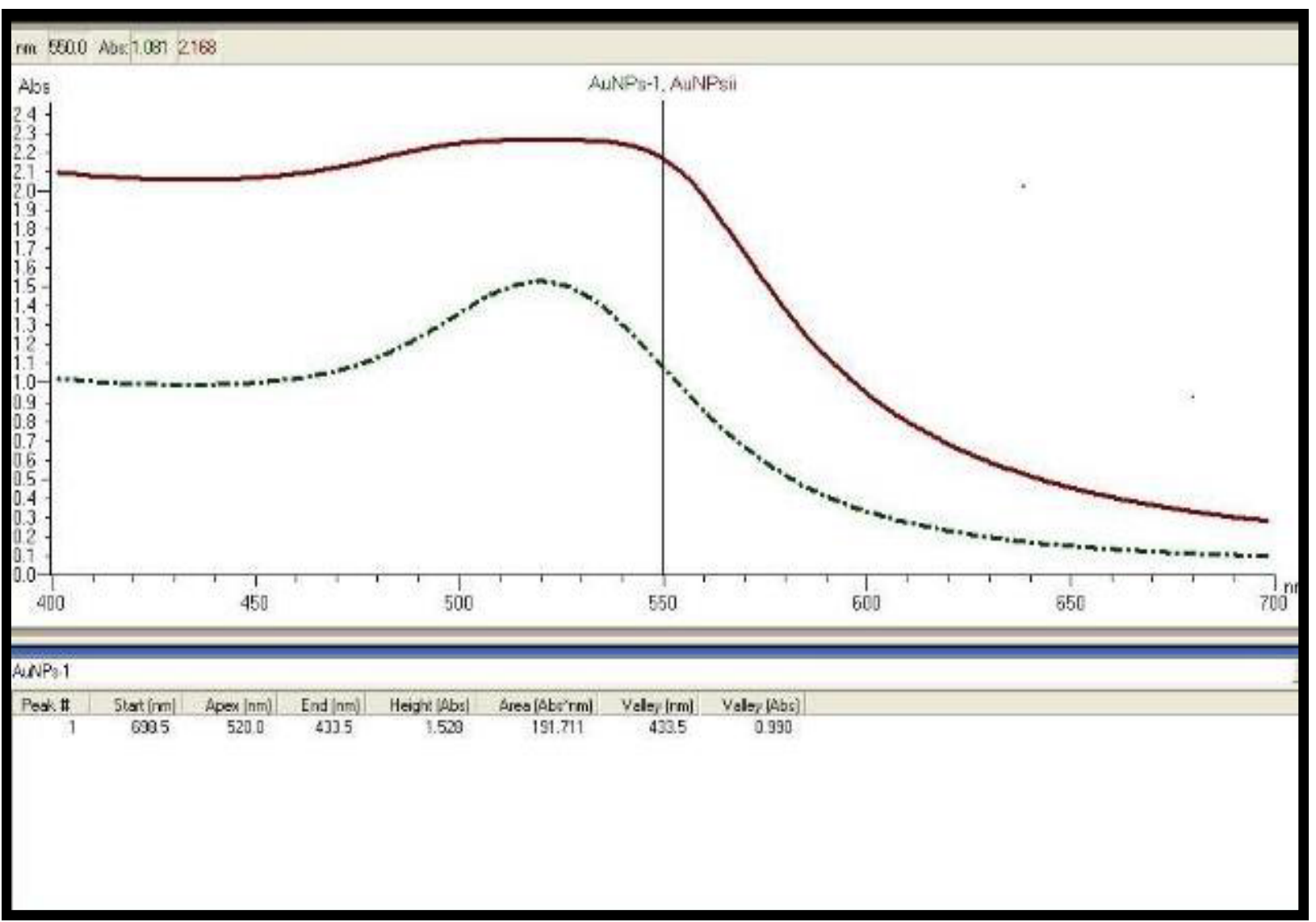

Figure 1: Ultra-Violet Visible Spectroscopy results of AuNPs showing peak at $520 \mathrm{~nm}$.

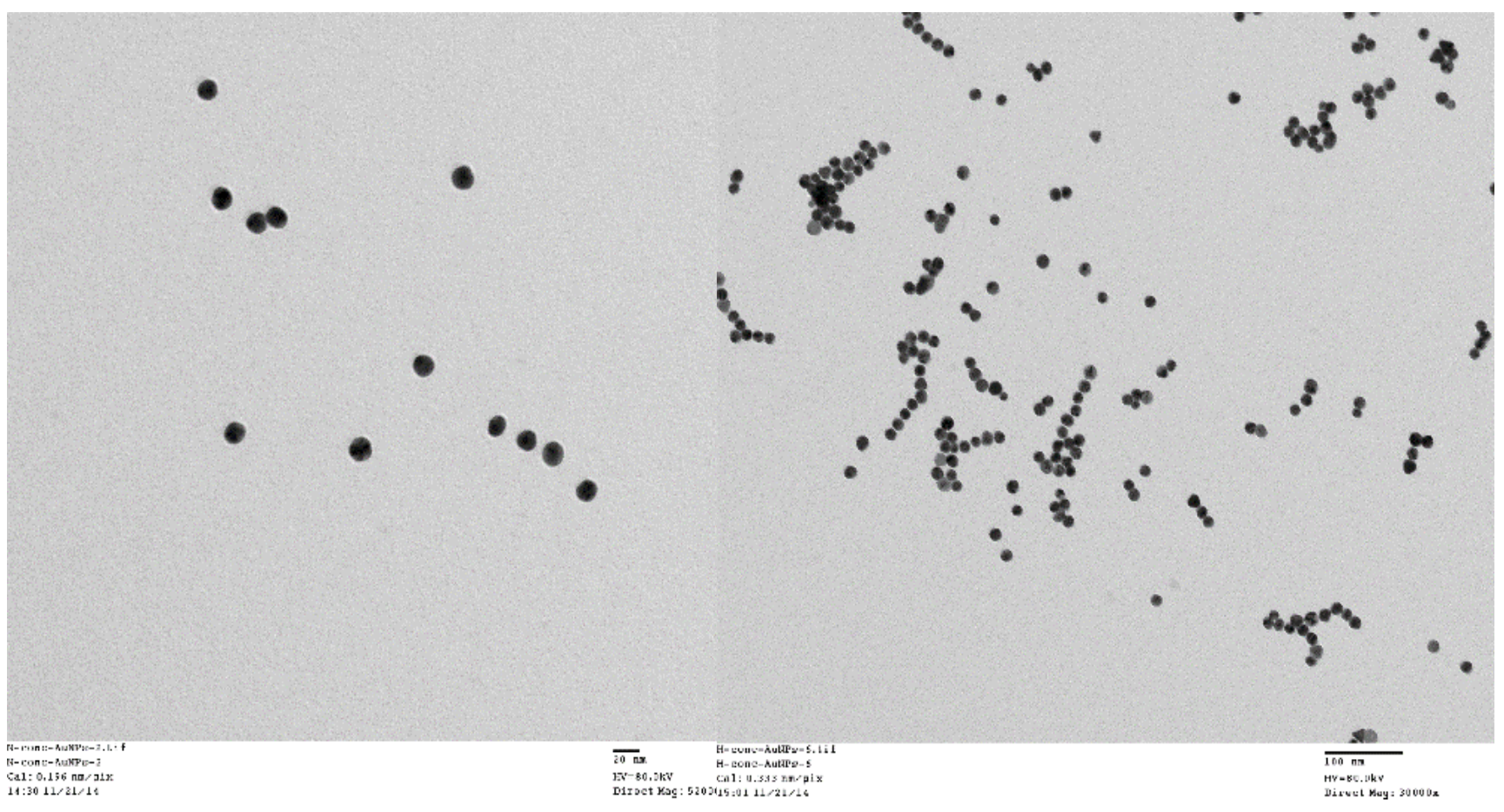

Figure 2: Spherical gold nanoparticles, $15-20 \mathrm{~nm}$ in size. 


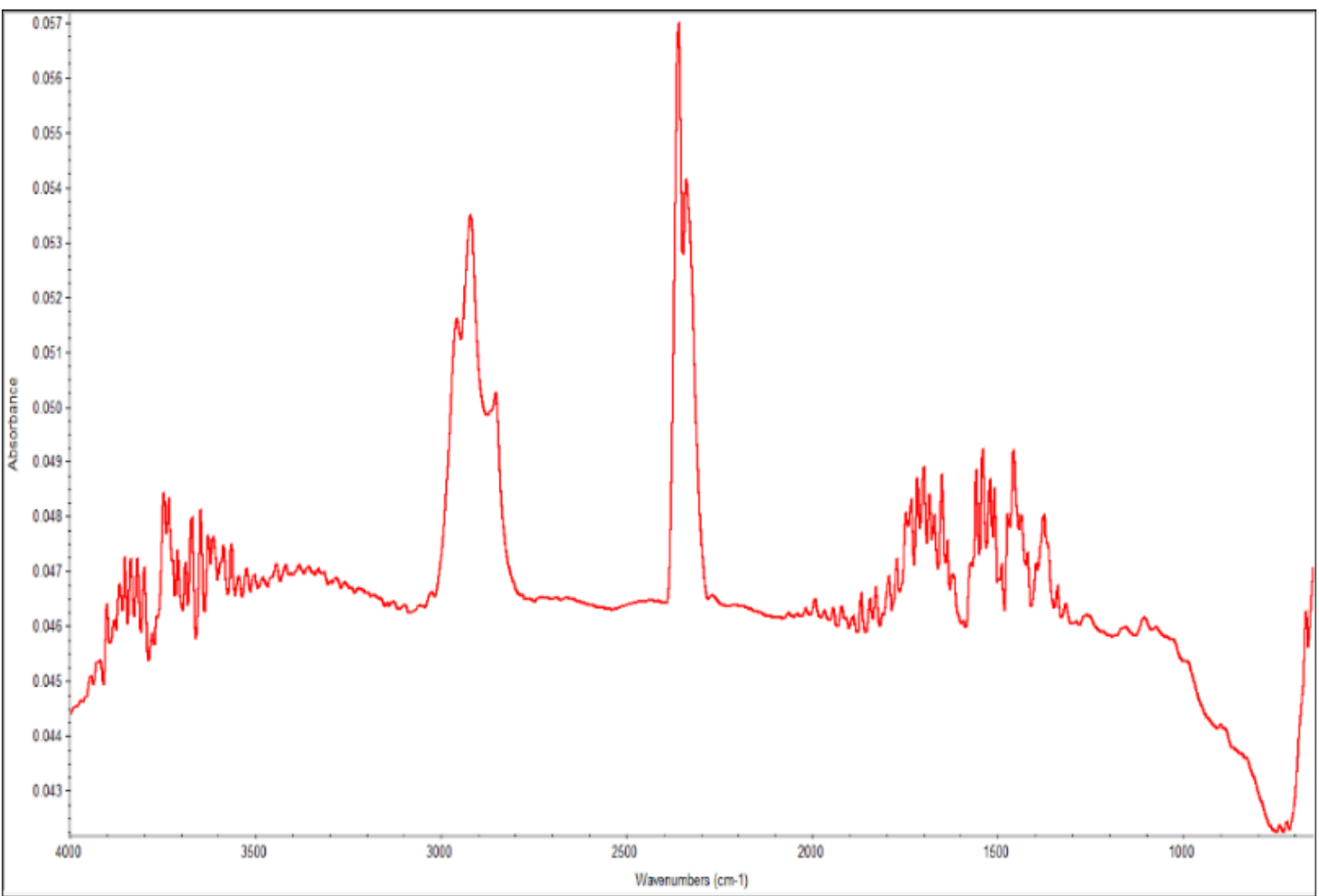

Figure 3: FTIR Boswellia sacra - Saturated Hydrocarbons $2000-3000 \mathrm{~cm}^{-1}$ - Terpenes.

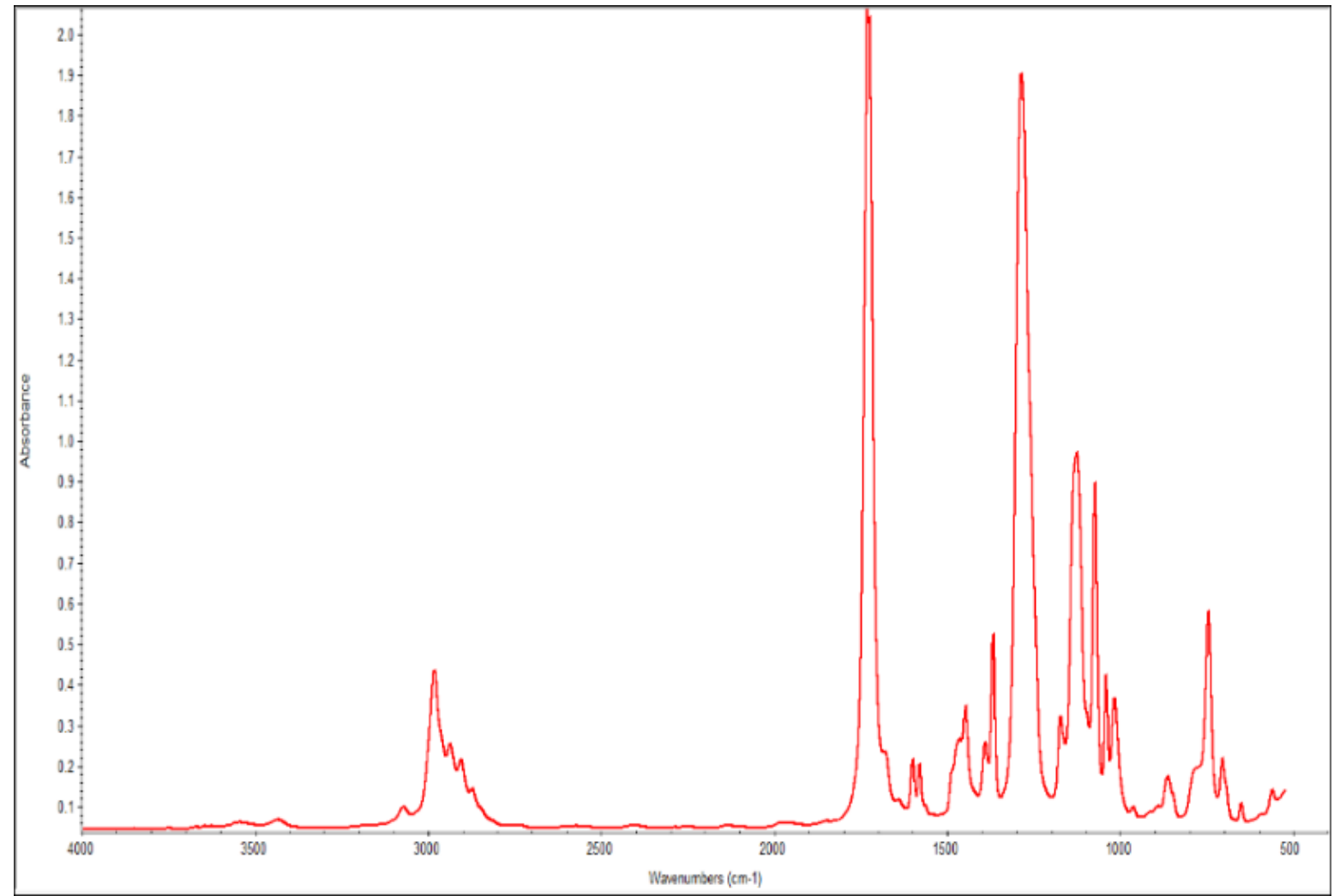

Figure 4: FTIR Commiphora myrrha - Unsaturated Hydrocarbons Below $2000 \mathrm{~cm}^{-1}$-Terpenoids. 


\begin{tabular}{|c|c|c|}
\hline Bond & Compound Type & Frequency Range, \\
\hline & & $\mathrm{Cm}^{-1}$ \\
\hline \multirow[t]{2}{*}{$\mathrm{C}-\mathrm{H}$} & Alkanes & $2960-2850$ (s) stretch \\
\hline & $\mathrm{CH} 3$ & $1380(\mathrm{~m}-\mathrm{w})$ Doublet \\
\hline \multirow[t]{2}{*}{$\mathrm{C}-\mathrm{H}$} & Alkenes & 3080-3020 (m) stretch \\
\hline & & 1000-675 (s) bend \\
\hline $\mathrm{C}-\mathrm{H}$ & Aromatic Rings & $3100-3000(\mathrm{~m})$ stretch \\
\hline $\mathrm{C}-\mathrm{H}$ & Alkynes & 3333-3267(s) stretch \\
\hline$C=C$ & Alkenes & $1680-1640(\mathrm{~m}, \mathrm{w}))$ stretch \\
\hline$C \equiv C$ & Alkynes & $2260-2100(w, s)$ stretch \\
\hline$C=C$ & Aromatic Rings & $1600,1500(w)$ stretch \\
\hline \multirow[t]{2}{*}{$\mathrm{C}-\mathrm{O}$} & Alcohols, Ethers, Esters, & $1260-1000(\mathrm{~s})$ stretch \\
\hline & Carboxylic Acids & \\
\hline \multirow[t]{2}{*}{$C=O$} & Aldehydes, Ketones, & 1760-1670(s) stretch \\
\hline & Carboxylic Acids, Esters & \\
\hline \multirow[t]{5}{*}{$\mathrm{O}-\mathrm{H}$} & Alcohols, Phenols, & 3640-3160(s, br) stretch \\
\hline & Carboxylic Acids & \\
\hline & Hydrogen Bonded & $3600-3200$ (b) stretch \\
\hline & Alcohols, Phenols & \\
\hline & Carboxylic Acids & $3000-2500$ (b) stretch \\
\hline \multirow[t]{2}{*}{$\mathrm{N}-\mathrm{H}$} & Amines & $3500-3300(\mathrm{~m})$ stretch \\
\hline & & $1650-1580(\mathrm{~m})$ bend \\
\hline $\mathrm{C}-\mathrm{N}$ & Amines & $1340-1020(\mathrm{~m})$ stretch \\
\hline$C \equiv N$ & Nitriles & $2260-2220(\mathrm{v})$ stretch \\
\hline \multirow[t]{7}{*}{ NO2 } & Nitro Compounds & $1660-1500(\mathrm{~s})$ \\
\hline & & asymmetrical stretch \\
\hline & & 1390-1260(s) symmetrical \\
\hline & & stretch \\
\hline & & v - variable, $\mathrm{m}$ - medium, \\
\hline & & s - strong, br - broad, \\
\hline & & w - weak \\
\hline
\end{tabular}

Table 1: Characteristic infrared absorption frequencies.

\begin{tabular}{|c|c|c|c|} 
Boswellia sacra & $\begin{array}{c}\text { Peak \#'s; } \\
\text { Area\% }\end{array}$ & Commiphora Myrrha & Peak \#'s; Area \% \\
\hline Alpha-Pinene & 5,$8 ; 44.72$ & Nitrofurantoin & $27 ; 39.891$ \\
\hline Limonene & $14 ; 13.35$ & Diethyl Phthalate & $26 ; 33.255$ \\
\hline Myrcene & $9 ; 8.16$ & Naphthalenes & Approximately $8 \%$ \\
\hline $\begin{array}{c}\text { Other Trace } \\
\text { Chemicals }\end{array}$ & & $\begin{array}{c}\text { Other Trace } \\
\text { Chemicals }\end{array}$ & \\
\hline
\end{tabular}

Table 2. GC-MS data

10A cells. MCF-7 and MDA-MB-231 breast cancer cell lines were used at the Brantley Laboratory, Loma Linda Medical School in Loma Linda, California. The dose response curves were plotted, and using a curvefitting program the percentage of the given mixtures that were able to cause a reduction in cell viability by $50 \%$ was determined. This is what is designated as the IC50. The cells were exposed to the compounds for 72 hours before performing the Alamar Blue assay. In addition, cells were visualized using relief contrast microscopy.

To investigate the anticancer effects in MDA-MB-231 cancer cells, the Alamar Blue ${ }^{\mathrm{Tm}}$ assay was performed, which estimates cell viability based on the conversion of dye from blue to a pink color. Cells were exposed for 72-hours with media containing either the gold nanoparticles in buffer alone or the gold nanoparticles in combination with the $\mathrm{BS}$ and $\mathrm{CM}$ compounds at both the regular and extra strengths. MDA-MB-231 cells showed greater sensitivity to the mixture than the MCF-7 cells, particularly using the extra strength mixture (IC50 $=0.013 \%$ vs. $0.04 \%$ ). Both cell types exhibited comparable sensitivity to the compound at the regular strength (IC50 $=0.13 \%$ vs. $0.15 \%$ ), as shown in Figure 9.
To determine whether the cytotoxic effects of the mixture were selective for malignant cells in comparison to nonmalignant cells, the non-tumorigenic MCF-10A cells were exposed to the compound at varying percentages in a similar fashion as the cancer cells. These cells were less susceptible to the actions of the compound, particularly using the extra strength dosage (IC50 $=0.19 \%)$. Boswellia sacra and Commiphora myrrha coupled with gold nanoparticles promoted breast cancer cell death.

Relief contrast microscopy was used to detect morphological changes in breast cancer cells reminiscent of programmed cell death or apoptosis. MDA-MB-231 and MCF-7 cells were treated with $0.1 \%$ at both strengths for 72 hours and then examined for formation of apoptotic bodies using relief contrast microscopy. Non-tumorigenic MCF-10A cells were also exposed to $0.1 \%$ of the regular and extra strength mixtures. Figure 10 shows no appreciable apoptotic body formation in MCF-10A cells, however, MDA-MB-231 and MCF-7 cells did exhibit apoptotic body formation, particularly at percentages of the respective strengths that exceeded the determined IC50 values.

\section{Discussion}

The aim of this study was to investigate the cytotoxic effect of gold nanoparticles conjugated with Boswellia sacra and Commiphora myrrha extracts on breast cancer cells. While breakthroughs in targeted therapy have emerged in recent years for breast cancer, such therapies have benefited those with breast cancer that express either the estrogen receptor, progesterone receptor or human epidermal growth factor receptor 2 (HER2). Patients with tumors that lack appreciable expression of the estrogen receptor, the progesterone receptor or HER2, designated as triple negative, still lack targeted therapy options and are thus restricted to using chemotherapy to address their malignancy.

Data in this study revealed that the triple negative MDA-MB-231 cells, which bear an aggressive phenotype, responded even more favorably to the compounds than the less aggressive, estrogen receptor positive, MCF-7 breast cancer cells. The diminished cytotoxicity observed when non-tumorigenic MCF-10A cells were exposed to the extra strength mixture (healthy cells) suggests that this mixture will offer promising treatment/therapy for patients with breast cancer cells with estrogen and progesterone receptors as well as the triple negative breast cells, with a higher potential for the more aggressive TNBCs, without causing harm to non-tumorigenic cells.

The development of synthesized/functionalized nanoparticles is generating increased interest in academia as well as industry. Several researchers agree that this exploration creates an avenue to a new standard where the different functionalized gold nanoparticles can be a powerful weapon against cancer [18]. The use of various nanoparticles to deliver genetic, medicinal, or other materials into cells is a leading trend in current nanobiotechnology coupled with its biomedical applications. The data on cellular uptake of gold nanoparticles is still insufficient to gain a complete understanding of the physical chemistry and biology of endocytosis and its dependence on particle parameters and cell types, however, it has been proven that at least, the cellular uptake of spherical gold nanoparticles is a receptor-mediated process by which the effectiveness depends on the size, smaller nanoparticles more effectively than larger nanoparticles, and the electrostatic interactions [19].

In conclusion, future research would include the observation of the use of this compound in human clinical trials, approval by the Food and Drug Administration (FDA), and advancement to the 


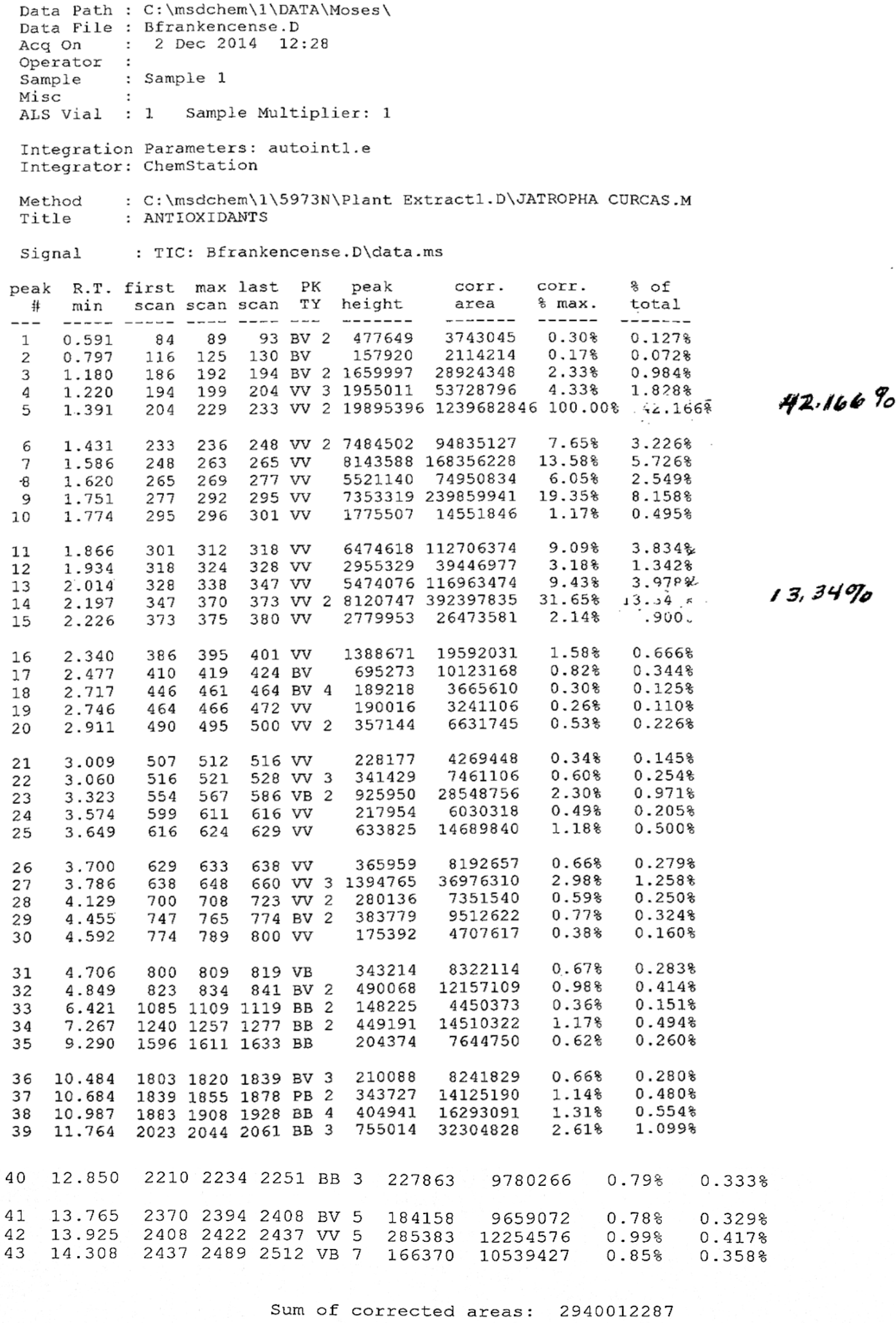

Sum of corrected areas: 2940012287

JATROPHA CURCAS.M TUE Dec 02 14:40:59 2014 6890N

Figure 5: GC-MS results for frankincense. 


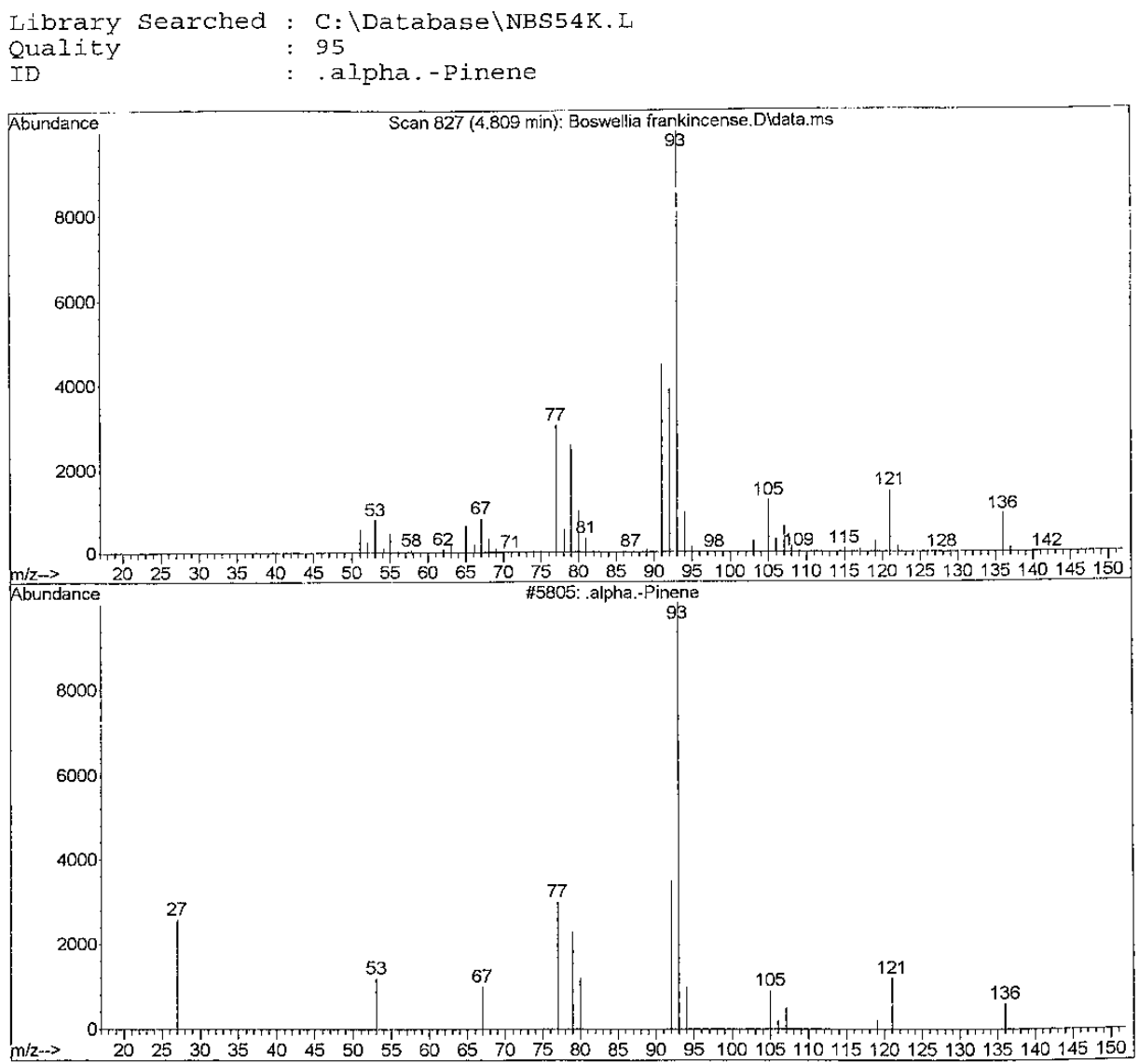

Figure 6: GC-MS spectra results for Boswellia sacra showing alpha-pinene as predominant Chemical.

pharmaceutical industry as soon as possible, in an effort to assist in the rampant fight against breast cancer. An issue for consideration during these trials should be that small nanoparticles, $1-20 \mathrm{~nm}$ in size, have long circulatory residence times and slower extravasation from the vasculature into interstitial spaces [20]. This may cause slower attainment of the maximal volume of distribution or an altered volume of distribution when administered intravenously [21]. Intravenous administration of nanoparticles prone to aggregation can result in pulmonary embolisms, strokes, myocardial infarctions and other microinfarctions at distant sites and organs [22]. It is imperative that a capping agent be used to prevent aggregation, and the suggested method of administration would be injection directly into the cancerous sites to reduce long circulatory times which could cause the functionalized nanoparticles to travel to or deposit in unnecessary areas of the body. An ideal approach would be to deliver these drugs to the primary tumors as well as at the site of metastasis and its microenvironment while monitoring the prognosis through non-invasive techniques. Nanoparticle drug delivery may reduce the dosage of anti-cancer drugs with better specificity, enhanced efficacy and lower toxicities.

Further research is suggested to completely understand the behavior of gold nanoparticles in the tumor microenvironment with consideration of physiological barriers in the environment due to the continuously changing nature of the tumor microenvironment. A possible suggestion is that the size, shape and surface chemistry of a nanoparticle would need to be optimized for each tumor and that they could be developed to respond to different properties of the tumor environment [23]. It would also be useful to further investigate the specific routes of endocytosis that are used by different nanoparticles which might involve using specific drug inhibitors of different endocytic pathways in an effort to identify the effects of cellular uptake of blocking pathways. Cytotoxicity studies would need to be conducted to determine the effect of internalization of the nanoparticles on these cells.

The combined effect of gold, frankincense and myrrh, introduced in historical biblical literature, seems to be a gift that was clearly prescribed since the beginning of time. It would be beneficial to many to use the anecdotes given so long ago, to affect a disease that has evidentially become a global concern. To the researcher's knowledge, no other compound, with these components, has been created and tested on these cancer cell lines. Aura-Bosphora (ABP) has been filed as a Utility Patent, pending with the United States Patent and Trademark Office.

\section{Acknowledgements}

This research was funded by the Title III Strengthening Grants Program, HBGI 2: Optics and Material Science Graduate Program, and the National Science Foundation under award number EPS-1158862. We would like to thank Brian Thomas, in the Department of Physics, Chemistry, and Mathematics at Alabama A\&M University for assistance with instrumentation, and the High Resolution Shared Imaging Facility at the University of Alabama in Birmingham (CCSG P30 CA 013148). We would also like to thank Dr. Stephanie Richardson, Pharmacologist (Martin Methodist College, Pulaski, TN) for her referral to the Brantley Cancer Research Laboratory. 


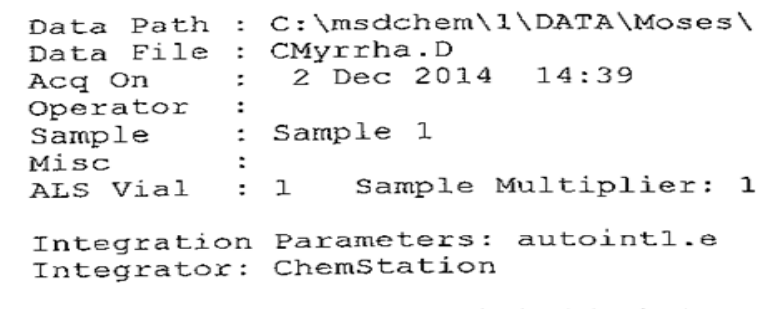

Method : C: Imsdchem $\backslash 1 \backslash 5973 \mathrm{~N} \backslash \mathrm{Plant}$ Extxact1.D\JATROPHA CURCAS.M Title : ANTIOXIDANTS

Sigral : TIC: CMyrrha.DIdata.ms

\begin{tabular}{|c|c|c|c|c|c|c|c|c|c|c|}
\hline $\begin{array}{c}\text { peak } \\
\# \\
---\end{array}$ & $\begin{array}{l}\mathrm{R}-\mathrm{T}- \\
\mathrm{min}\end{array}$ & $\begin{array}{c}\text { Eirst } \\
\text { scan }\end{array}$ & $\begin{array}{r}\max \\
\operatorname{scan} \\
----\end{array}$ & $\begin{array}{l}\text { last } \\
\text { scan }\end{array}$ & $\begin{array}{l}\text { PK } \\
\text { TY }\end{array}$ & & $\begin{array}{c}\text { peak } \\
\text { height }\end{array}$ & $\begin{array}{l}\text { corr. } \\
\text { area }\end{array}$ & $\begin{array}{l}\text { corr. } \\
8 \text { max. }\end{array}$ & $\begin{array}{l}8 \text { of } \\
\text { total }\end{array}$ \\
\hline 1 & 9.147 & 1560 & 1586 & 1595 & $\mathrm{BV}$ & 4 & 219238 & ------ & ------ & ------- \\
\hline 2 & 9.301 & 1595 & 1613 & 1642 & VB & 4 & $\begin{array}{r}219238 \\
1190356\end{array}$ & 10564563 & 0.248 & $\begin{array}{l}0.097 \% \\
0.494 \%\end{array}$ \\
\hline 3 & 10.341 & 1779 & 1795 & 1807 & vV & 3 & 200822 & $\begin{array}{r}53506158 \\
8832997\end{array}$ & $\begin{array}{l}1.24 \% \\
0.20 \%\end{array}$ & $\begin{array}{l}0.4948 \\
0.0818\end{array}$ \\
\hline 4 & 10.524 & 1807 & 1827 & 1844 & VV & 2 & 1622383 & 79119133 & $1.83 \%$ & 0.730 s \\
\hline 5 & 10.713 & 1844 & 1860 & 1893 & $\mathrm{vV}$ & 2 & 1110519 & 54186663 & 1.258 & $0.500 \%$ \\
\hline $\begin{array}{l}6 \\
7\end{array}$ & 11.081 & 1893 & 1925 & 1935 & PV & 3 & 2865297 & 160240653 & $3.71 \%$ & 1. 478 응 \\
\hline $\begin{array}{l}7 \\
8\end{array}$ & 11.764 & 2023 & 2044 & 2054 & VV & 6 & 500665 & 23635366 & $0.55 \%$ & 0.2188 \\
\hline $\begin{array}{l}8 \\
9\end{array}$ & 11.873 & 2054 & 2063 & 2079 & VV & 2 & 521791 & 22530087 & 0.528 & $0.208 \%$ \\
\hline $\begin{array}{r}9 \\
10\end{array}$ & 12.050 & 079 & 2094 & 2101 & $\mathrm{VV}$ & 4 & 204456 & 8837494 & $0.20 \%$ & $0.082 \%$ \\
\hline 10 & 12.136 & 2101 & 2109 & 2128 & VV & 4 & 243300 & 10715953 & $0.25 \%$ & 0.0998 \\
\hline $\begin{array}{l}11 \\
12\end{array}$ & 12.416 & 2128 & 2158 & 2174 & PV & & 1275943 & 59228506 & 1.378 & $0.546 \%$ \\
\hline $\begin{array}{l}12 \\
13\end{array}$ & 12.622 & 2174 & 2194 & 2215 & VV & 5 & 716833 & 34898345 & 0.818 & 0.3228 \\
\hline $\begin{array}{l}13 \\
14\end{array}$ & 12.873 & 2215 & 2238 & 2255 & VV & 3 & 336598 & 17779104 & $0.41 \%$ & 648 \\
\hline $\begin{array}{l}14 \\
15\end{array}$ & $\begin{array}{l}13.793 \\
13.993\end{array}$ & $\begin{array}{l}2367 \\
2414\end{array}$ & $\begin{array}{l}2399 \\
2434\end{array}$ & $\begin{array}{l}2414 \\
2446\end{array}$ & $\begin{array}{l}\text { VV } \\
\text { VV }\end{array}$ & $\begin{array}{l}6 \\
6\end{array}$ & $\begin{array}{r}813567 \\
1248992\end{array}$ & 59239777 & $1.37 \%$ & $\begin{array}{l}0.547 \% \\
0.684 \%\end{array}$ \\
\hline & & & & & & & & & & $0.684 \%$ \\
\hline 17 & $\begin{array}{l}14.193 \\
14.388\end{array}$ & & $\begin{array}{l}2469 \\
2503\end{array}$ & 2478 & VV & 3 & 2164641 & 128872465 & $2.98 \%$ & 1.1898 \\
\hline 18 & 14.605 & $\begin{array}{l}2478 \\
2524\end{array}$ & $\begin{array}{l}2503 \\
2541\end{array}$ & 2524 & vV & 3 & 3163 & 233782337 & 5.418 & $2.157 \%$ \\
\hline 19 & 14.822 & 2563 & $\begin{array}{l}2541 \\
2579\end{array}$ & 2563 & vV & 6 & 1413966 & 80812767 & $1.87 \%$ & 0.7468 \\
\hline 20 & 14.988 & 2591 & $\begin{array}{l}2579 \\
2608\end{array}$ & 2591 & VV & 8 & 341323 & 20094049 & 0.468 & $0.185 \%$ \\
\hline & & & 2008 & $20<4$ & v & 7 & 346379 & 29583922 & $0.68 \%$ & 0.2738 \\
\hline 22 & $\begin{array}{l}15.439 \\
15.674\end{array}$ & $\begin{array}{l}2664 \\
2702\end{array}$ & $\begin{array}{l}2687 \\
2728\end{array}$ & 2702 & VV & 2 & 1264534 & 60353060 & $1.40 \%$ & $0.557 \%$ \\
\hline 23 & 15.834 & 2747 & $\begin{array}{l}2728 \\
2756\end{array}$ & 2747 & VV & 4 & 639268 & 4909 & 1.1 & $0.453 \%$ \\
\hline 24 & 16.057 & 2766 & $\begin{array}{l}2756 \\
2795\end{array}$ & 2766 & VV & 8 & 259103 & 13368111 & 0.318 & 0.123 용 \\
\hline 25 & 17.200 & 2903 & $\begin{array}{l}2795 \\
2995\end{array}$ & 2828 & VV & 6 & 943550 & 74325335 & $1.72 \%$ & $0.686 \%$ \\
\hline & & & & 3005 & $\mathrm{BV}$ & & 3622786 & 553376410 & $12.80 \%$ & $5.105 \%$ \\
\hline 27 & $\begin{array}{l}18.148 \\
18.869\end{array}$ & 3168 & $\begin{array}{l}3161 \\
3287\end{array}$ & 3168 & vV & 3 & 8957889 & 3604796745 & $83.36 \%$ & 33.255 \\
\hline 28 & 18.971 & 3295 & $\begin{array}{l}3287 \\
3305\end{array}$ & $\begin{array}{l}3295 \\
3335\end{array}$ & VV & & 11959501 & 14324151102 & 100.00 & 39.891 \\
\hline 29 & 19.217 & 3335 & $\begin{array}{l}3305 \\
3348\end{array}$ & $\begin{array}{l}3335 \\
3360\end{array}$ & $\begin{array}{l}\text { VV } \\
\text { VV }\end{array}$ & $\begin{array}{l}8 \\
6\end{array}$ & 2538689 & 263707989 & $6.10 \%$ & $2.433 \%$ \\
\hline 30 & 19.360 & 3360 & $\begin{array}{l}3348 \\
3373\end{array}$ & $\begin{array}{l}3360 \\
3392\end{array}$ & VV & $\begin{array}{l}6 \\
7\end{array}$ & $\begin{array}{r}1100636 \\
977847\end{array}$ & 69901316 & 1.628 & $0.645 ㅇ ㅡ ㅇ$ \\
\hline & & & & 列 & & & 977847 & 60477019 & $1.40 \%$ & $0.558 \%$ \\
\hline 32 & 19.772 & 3413 & $\begin{array}{l}3403 \\
3445\end{array}$ & 13 & VV & 6 & 9211 & 8182 & 0.368 & 0.1428 \\
\hline 33 & 19.937 & 3457 & $\begin{array}{l}3445 \\
3474\end{array}$ & 3457 & VV & 9 & 697037 & 61329274 & $1.42 \%$ & 0.5668 \\
\hline 34 & 20.235 & 3505 & $\begin{array}{l}3474 \\
3526\end{array}$ & 3505 & VV & 9 & 740671 & 64812580 & $1.50 \%$ & $0.598 \%$ \\
\hline 35 & 20.435 & 3546 & $\begin{array}{l}3526 \\
3561\end{array}$ & 3546 & VV & 7 & 282101 & 26982655 & $0.62 \%$ & 0.2498 \\
\hline & & & 3561 & 3573 & VV & 4 & 338628 & 20919389 & $0.48 \%$ & 0.193 용 \\
\hline $\begin{array}{l}36 \\
37\end{array}$ & $20 \cdot 9$ & 3631 & 3650 & 3682 & VV & 4 & 486367 & 32857592 & $0.76 \%$ & 0.3038 \\
\hline $\begin{array}{l}37 \\
38\end{array}$ & 21.823 & 3781 & 3804 & 3822 & VV & 8 & 309199 & 19259313 & $0.45 \%$ & $0.178 \%$ \\
\hline $\begin{array}{l}38 \\
39\end{array}$ & 22.229 & 3843 & 3875 & 3896 & VV & 3 & 1569322 & 103727895 & $2.40 \%$ & 0.957종 \\
\hline & $22 \cdot 713$ & 3939 & 3960 & 3974 & ve & 3 & 518850 & 25191074 & $0.58 \%$ & $0.232 \%$ \\
\hline 10 & 22.926 & 3974 & 3997 & 4013 & $\mathrm{PV}$ & 3 & 213334 & 10671445 & $0.25 \%$ & .0988 \\
\hline 41 & 23. & & 4176 & 4191 & $B V$ & 4 & 168557 & 8756184 & $0.20 \%$ & .0818 \\
\hline 42 & 24.355 & 4210 & 4247 & 4261 & VV & 2 & 1943950 & 32488034 & $3.06 \%$ & $1.222 \%$ \\
\hline 43 & 25.618 & 4436 & 4468 & 4494 & $\mathrm{VB}$ & 2 & 1248371 & 73205896 & 1.69 영 & .6758 \\
\hline
\end{tabular}


* Search Report Page 1 of $1^{\text {** }}$

Unknown: Scan $2063(11.873 \mathrm{~min})$ : CMyrrha. Didata.ms
Compound in Library Factor $=-104$

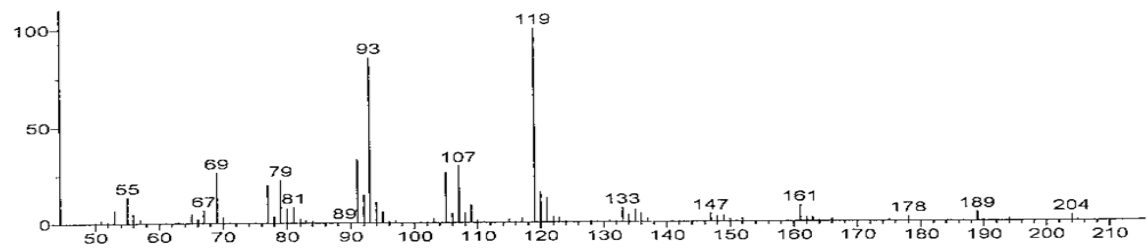

Hit 1 : Bicyclo[3.1.1]hept-2-ene, 2,6-dimethyl-6-(4-methyl-3-pentenyl)-
C15H24; MF: 907; RMF: 947; Prob 48.7\%; CAS: 17699-05-7; Lib: mainlib; 1D: 59859.

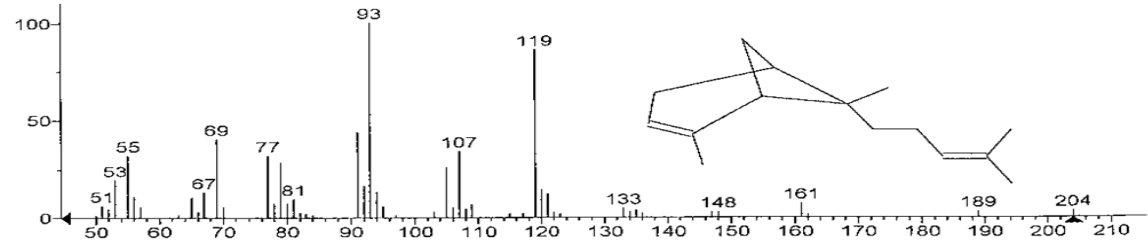

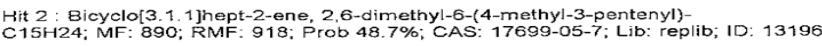

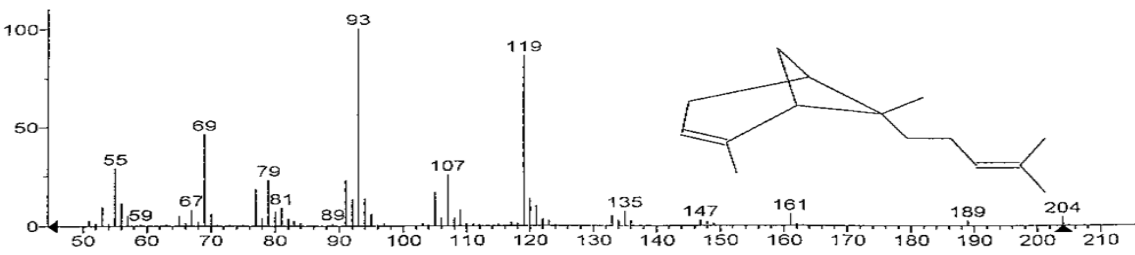

Figure 8: GC-MS spectra results for Commiphora myrrha showing sesquiterpenoids as predominant chemical.

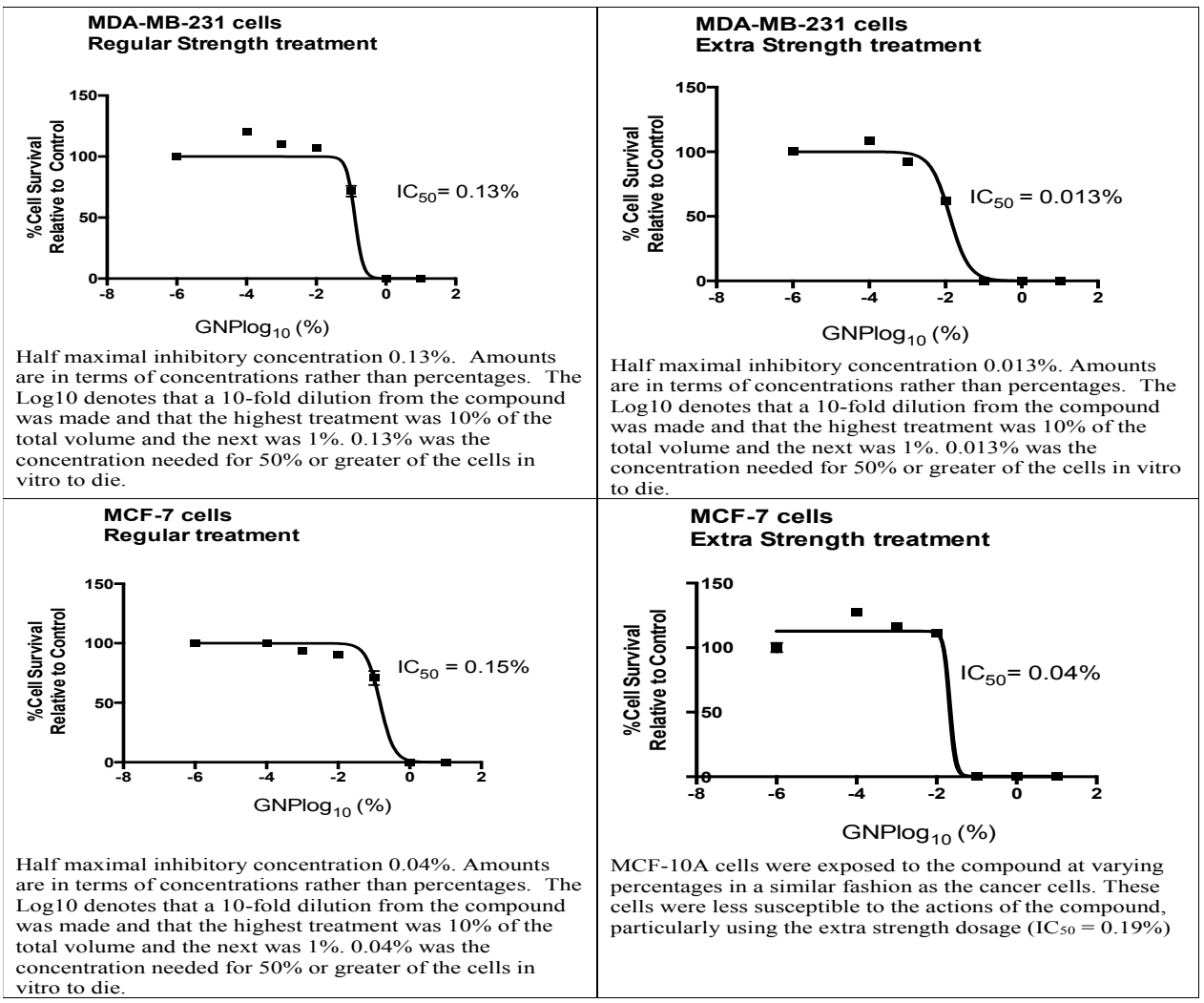

Figure 9: IC-50 data 
Citation: Moses SL, Edwards VM, Brantley E (2016) Cytotoxicity in MCF-7 and MDA-MB-231 Breast Cancer Cells, without Harming MCF-10A Healthy Cells. J Nanomed Nanotechnol 7: 369. doi:10.4172/2157-7439.1000369
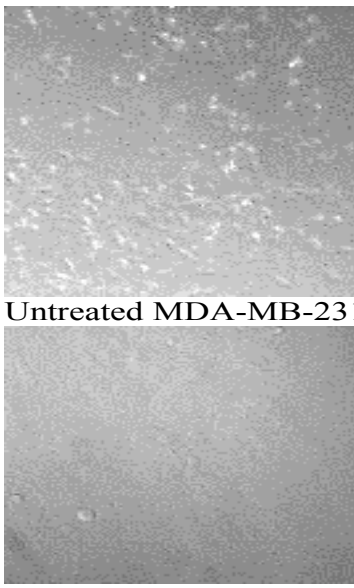

Untreated MCF-7

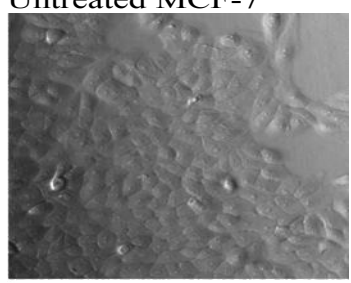

Untreated MCF-10A
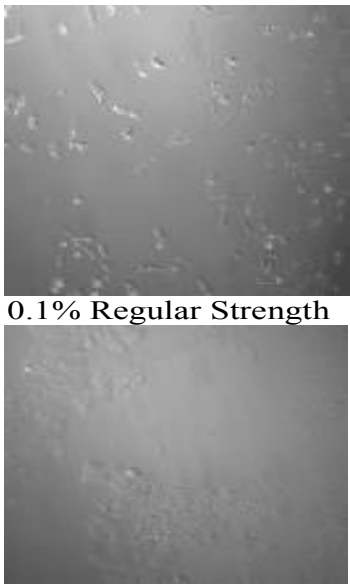

$0.1 \%$ Regular Strength

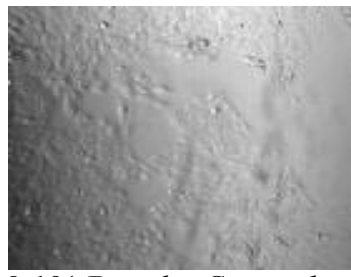

$0.1 \%$ Regular Strength

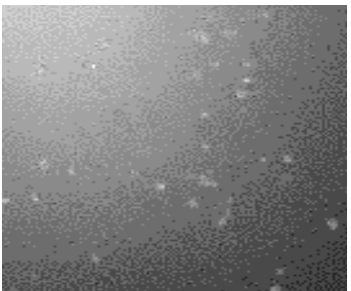

$0.1 \%$ Extra Strength

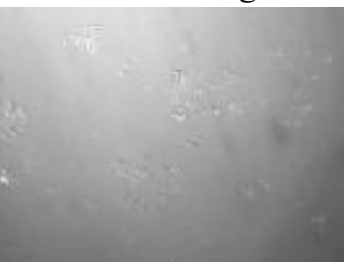

$0.1 \%$ Extra Strength

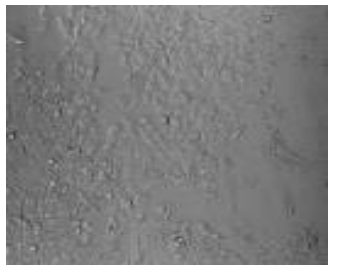

$0.1 \%$ Extra Strength

Figure 10: Cell lines before and after treatment.

\section{References}

1. Kohler B, Sherman R, Howlader N, Jemal A, Ryerson B, Henry K, et al. (2015) Annual report to the nation on the status of cancer, 1975-20, featuring incidence of breast cancer subtypes by race/ethnicity, poverty, and state. Journal of the National Cancer Institute.

2. Ferlay J, Soerjomataram I, Ervik M, Dikshit R, Eser S, et al. (2013) GLOBOCAN 2012 v1 . O, Cancer Incidence and Mortality Worldwide: IARC CancerBase No. 11. Lyon France: International Agency for Research on Cancer

3. Kahn A, Rashid R, Murtaza G, Zahra A (2014) Gold nanoparticles: synthesis and applications in drug delivery. Tropical Journal of Pharmaceutical Research 13: 1169-1177.

4. Kandela I (2012) Producing and Conjugating Colloidal Metals. University of Wisconsin-Madison.

5. Ngwa W, Kumar R, Sridhar S, Korideck H, Zygmanski P, et al. (2014) Targeted radiotherapy with gold nanoparticles: current status and future perspectives. Nanomedicine (Lond) 9: 1063-1082.

6. Kodiha M, Wang YM, Hutter E, Maysinger D, Stochaj U (2015) Off to the organelles - killing cancer cells with targeted gold nanoparticles. Theranostics 5: 357-370.

7. Ranganathan R, Madanmohan S, Kesavan A, Baskar G, Krishnamoorthy YR, et al. (2012) Nanomedicine: towards development of patient-friendly drug-delivery systems for oncological applications. Int J Nanomedicine 7: 1043-1060.

8. Ernst E1 (2008) Frankincense: systematic review. BMJ 337: a2813.

9. Hamidpour R, Hamidpour S, Hamidpour M, Shahlari M (2013) Frankincense rÇ" xiÄ ng; boswellia species): from the selection of traditional applications to the novel phytotherapy for the prevention and treatment of serious diseases. $J$ Tradit Complement Med 3: 221-226.

10. Mothana R, Hasson S, Schultze W, Mowitz A, Lindequis U (2011) Phytochemical composition and in vitro antimicrobial and antioxidant activities of essential oils of three endemic soqotraen boswellia species. Food Chem 126 1149-1154.

11. Zielinski E (2015) Frankincense oil shown to kill cancer and boost immunity.

12. Mahmoud S (2015) Healing support for cancer: frankincense.

13. Shen T, Li GH, Wang XN, Lou HX (2012) The genus Commiphora: a review of its traditional uses, phytochemistry and pharmacology. J Ethnopharmaco 142: 319-330.
14. Al Faraj S (2005) Antagonism of the anticoagulant effect of warfarin caused by the use of commiphora molmol as an herbal medication: A case report. Annals of tropical medicine and parasitology 99: 219-220.

15. Su S, Hua Y, Wang Y, Gu W, Zhou W, et al. (2012) Evaluation of the antiinflammatory and analgesic properties of individual and combined extracts from Commiphora myrrha, and Boswellia carterii. J Ethnopharmacol 139: 649-656.

16. Gawade S (2012) Acetic acid induced painful endogenous infliction in writhing test on mice. J Pharmacol Pharmacother 3: 348

17. Chen Y, Zhou C, GE Z, Liu Y, Liu Y, et al. (2013) Composition and potential anticancer activities of essential oils obtained from myrrh and frankincense. Oncology Letters 6: 1140-1146.

18. Raghunandan D, Ravishankar B, Sharanbasava G, Mahesh DB, Harsoor V, et al. (2011) Anti-cancer studies of noble metal nanoparticles synthesized using different plant extracts. Cancer Nanotechnol 2: 57-65.

19. Dykman L, Khlebtsov N (2014) Uptake of engineered gold nanoparticles into mammalian cells. Chemical Reviews 114: 1258-1288.

20. Winter PM, Caruthers SD, Kassner A, Harris T, Chinen L, et al. (2003) Molecula imaging of angiogenesis in nascent vx-2 rabbit tumors using a novel alpha (nu) beta3-targeted nanoparticle and 1.5 tesla magnetic resonance imaging. Cancer Res 63: 5838-5843.

21. Moghimi S, Bonnemain B (1999) Subcutaneous and intravenous delivery of diagnostic agents to the lymphatic system: applications in lymphoscintigraphy and indirect lymphography. Advance Drug Delivery Rev 37: 295-312.

22. Kohane DS, Plesnila N, Thomas SS, Le D, Langer R, et al. (2002) Lipid-suga particles for intracranial drug delivery: safety and biocompatibility. Brain Res 946: 206-213.

23. Jain RK, Stylianopoulos T (2010) Delivering nanomedicine to solid tumors. Nat Rev Clin Oncol 7: 653-664. 